\title{
Kronik Hastalığı Olan Çocukların Bakımında Okul Hemşiresinin Görev ve Sorumlulukları
}

\author{
Gizem ÇAKIR*, Naime ALTAY**
}

$\ddot{O} \mathbf{z}$

Kronik hastalık, prevalansı yıllar geçtikçe artan, tıbbi bakım gerektiren, çocukları fiziksel, psikososyal ve akademik olarak etkileyen bir durumdur. Kronik hastalığı olan çocukların günlük gereksinimleri sağlıklı akranlarından farklılık gösterebilmektedir. Kronik hastalığı olan okul dönemindeki çocukların okulda ilaç kullanma, ölçüm yapma, beslenme, hareket etme, solunum ve boşaltım ile ilgili fiziksel gereksinimleri bulunmaktadır. Kronik hastalığı olan çocukların psikososyal ve davranışsal değişiklik gösterdiği ve psikososyal olarak desteklenmesi gerektiği belirtilmiştir. Çocukların motivasyonunun artması için desteklenmeye gereksinimleri bulunmaktadır. Okulda kronik hastalık yönetiminin sağlanabilmesinde okul hemşiresine olan gereksinim kaçınılmazdır. Bu derlemede kronik hastalığı olan çocukların okuldaki gereksinimlerinin karşılanması ve bakımında okul hemşiresinin görev ve sorumlulukları, bakım, eğitim, sağlık politikaları ve yönetsel yönleri ele alınmıştır. Anahtar Kelimeler: Çocuk, kronik hastalık, bakım, okul hemşiresi.

Abstract

Duties and Responsibilities of School Nurses in Care of Children with Chronic Disease

Chronic disease is a condition which prevalence has increased over the years, requiring medical care, affecting children physically, psychosocially and academically. Daily needs of children with chronic diseases may differ from their healthy peers. They may need medication and blood glucose, nutrition and excretion monitoring at school. Associations between chronic diseases and emotional, behavioural, social and overall vulnerabilities were reported. The children should be supported psychosocially. Children need support to increase their motivation. The needs for a school nurse is inevitable in ensuring chronic disease management at school. In this review, the duties and responsibilities of the school nurse, care education, health policies and managerial aspects and care of the needs of children with chronic diseases are discussed.

Key Words: Child, chronic disease, care, school nurse.

Geliş tarihi: 02.05.2020 Kabul tarihi: 16.11.2020

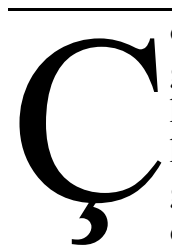

ocukluk çağı kronik hastalıkları yaşamı uzun süre etkileyebilmektedir. Bu durum dünyada önemli bir sorun haline gelmiştir. Dünyada kronik hastalı̆̆ı olan çocukların insidansı \%10-15 olarak belirtilmiştir. Çocuklar kronik hastalıkların getirdiği güçlük ve sorumluluklarla başa çıkmak durumundadırlar (1). Kronik hastalığı olan çocukların hastalık ve tedavileri (ilaç kullanma, ölçüm yapma, rehabilitasyon vb.) nedeniyle sağlıklı akranlarına göre gereksinimleri farklılık göstermektedir (2). Çocukların bu gereksinimleri, yaşam tarzı değişikliklerinin, psikososyal durumunun ve okul yaşamlarının olumsuz yönde etkilenmesine neden olabilmektedir (3). Kronik hastalığı olan çocukların okulda yaşadıkları sorunların önlenebilmesi ve giderilebilmesi için fiziksel, psikososyal ve akademik gereksinimlerinin belirlenmesi ve karşılanması hakkında farkındalığın oluşması gerekmektedir (4). Okullarda kronik hastalığı olan çocukların bakım yönetimi sağlık profesyonelleri tarafından yapılmalıdır. Okul hemşiresi, kronik hastalığı olan çocukların sağlık bakım gereksinimlerinin karşılanmasında anahtar rolü üstlenmektedir (5). Okul hemşiresi, okul sağlığı programlarının etkin bir şekilde uygulanabilmesi için sağlık ve eğitim sisteminin bütünleşik olarak yürütülmesini sağlamaktadır. Okul hemşireliği uygulamaları çocukların ve ebeveynlerin yaşam kalitesini iyileştirir (6). Okul hemşireliği uygulamalarının toplum ve ülke ekonomisine olan faydaları bilinmektedir (7). Wang ve arkadaşlarının (2019) çalışmasında, okul hemşireliği hizmetinin çocukların sağlık bakım hizmeti giderlerinin azalmasında etkili olduğu belirlenmiştir (8). Bu derlemenin amacı kronik hastalı ğı olan çocukların gereksinimlerinin karşılanması ve bakımında okul hemşiresinin görev ve sorumluluklarının incelenmesidir. Derleme, kronik hastalık, kronik hastalığı olan çocukların okuldaki gereksinimleri ve okul hemşiresinin görev ve sorumlulukları olarak üç ana başlık altında ele alınmıştır.

\section{Kronik Hastalık}

Kronik hastalık, genetik, fizyolojik, çevresel ve davranışsal faktörlerin kombinasyonu sonucunda meydana gelen, genellikle bir yıl veya daha uzun süren, sürekli tıbbi müdahale gerektiren ve günlük yaşam aktivitelerini sınırlayan durumlar olarak tanımlanmaktadır $(9,10)$. Kronik hastalığı olan çocuğa özgü, bütüncül bakım vermede zamana bağlı model, kronik hüzün modeli, birleşik model ve aile sistemleri hastalık modeli gibi çeşitli modeller kullanılmaktadır. Bu modeller çocuğun kronik hastalığına ailenin tepkilerini açıklamaktadır. Okul hemşiresi bakımda bu modelleri kullanarak kronik hastalığı olan çocuk ve ailesini kapsamlı bir şekilde değerlendirebilir. Bakım planlamasını bütüncül bir çerçevede ele alabilir (11-13). Kronik hastalığı olan çocukların prevalansı yıllar geçtikçe artmaktadır. CDC'nin ulusal verilerine göre; 2017 yılında çocuklarda görülen astım prevalansı \%8.4'tür (14), her 1000 çocuktan 6'sında epilepsi olduğu tahmin edilmektedir (15) ve otizm prevalansı 2014 yılında 16.8/1000 (her 59 çocuktan birisi)'dir (16). Türkiye Engelliler Araştırması (2002)'nın raporuna göre 0-9 yaş aralığında olan çocukların \%2.6'sının ve 10-19 yaş aralığında olan çocukların \%2.7'sinin kronik hastalığı olduğu belirtilmiştir. Türkiye'de kronik hastalığı olan 0-19 yaşları arasında 698.406 çocuk bulunduğu ifade edilmiştir (17). Okul çağı çocuklarında en sık görülen kronik hastalıklar arasında astım, kanser, kistik fibrozis, serebral palsi, kronik böbrek yetmezliği, malnutrisyon, diyabet (18), epilepsi, otizm, obezite ve dikkat ve hiperaktivite bozukluğu yer almaktadır (19).

*Arş. Gör. Gazi Üniversitesi Sağlık Bilimleri Fakültesi Hemşirelik Bölümü, Çocuk Sağlığı ve Hastalıkları Hemşireliği AD. Ankara/Türkiye. E-posta: gizemcakir@gazi.edu.tr Orcid No: 0000-0002-8308-5817. ** Doç. Dr. Gazi Üniversitesi Sağlık Bilimleri Fakültesi Hemşirelik Bölümü, Çocuk Sağlı̆̆ı ve Hastalıkları Hemşireliği AD. Ankara/Türkiye. Orcid No: 0000-0003-1524-3390 


\section{Kronik Hastalı̆̆ı Olan Çocukların Okuldaki Gereksinimleri}

Kronik hastalı̆̆ı olan çocukların özel gereksinimleri olabilmektedir (20). Kronik hastalığı olan çocukların gereksinimleri çocuğun fiziksel, bilişsel, duygusal, davranışsal, sosyal, gelişimsel özelliğine, semptomlara ve sıklı̆̆ına bağlı olarak değişebilmektedir (21). Kronik hastalı̆ğ olan okul dönemi çocuklarının gereksinimleri fiziksel, psikososyal ve akademik gereksinimler olmak üzere 3 başlık altında incelenmiştir.

\section{Fiziksel Gereksinimler}

Her çocuğun fiziksel gereksinimi gelişim dönemi özelliğine ve hastalığına göre farklılık gösterebilmektedir (1). Kronik hastalığı olan çocukların okuldaki fiziksel gereksinimleri arasında, ilaçların uygulanması, ölçümlerin yapılması, beslenme ve diyetin düzenlenmesi, uygun çevre düzenlemesi ve fiziksel aktivitelerin düzenlenmesi yer almaktadır. Çocukların okul saatlerinde ilaçlarını uygulaması ya da ölçüm yapması gerekebilir. Örneğin, Tip 1 diyabeti olan çocukların okulda kan glikozunu ölçme, insülin ilacını uygulama gibi gereksinimleri vardır (3). Bazı kronik hastalıklarda çocukların beslenme ile ilgili gereksinimleri bulunabilir (22). Kronik hastalıkların çocukların büyümesini olumsuz olarak etkilediği belirtilmektedir (23). Kronik hastalıkların büyüme ve gelişme üzerindeki etkilerini önlemek için çocuğun beslenmesi değerlendirilir ve çocuğa özgü bireysel beslenme planı yapılır $(22,23)$. Örneğin, kronik böbrek yetmezliği olan çocukların kalorisi yüksek besin alması sağlanırken protein alımı azaltılır (24). Diyabeti olan çocukların aldığı besinlerin karbonhidrat sayımı yapılır ve ara öğünlerini alması sağlanır (25). Serebral palsi tanılı çocukların disfaji, gastroözefajial reflü ve konstipasyon gibi gastrointestinal sorunları nedeniyle okulda beslenmeyi erteleme durumu, beslenme sırasında aspirasyon riski ve yardıma gereksinimi olabilmektedir (23). Örneğin disfajisi olan çocukların yüksek kalorili, sıvı besinler alması gerekir. Konstipasyonu olan çocuklara lifli besinler verilir ve günlük sıvı alımının yeterli olması sağlanır. Çocukların diyetine uygun beslenebilmesi için okul kantininde ve yemekhanede bulunan yiyecekler uygun olmalıdır (26).

Kronik hastalığı olan çocukların fiziksel aktivitelere katılımları sağlıklı akranlarına göre düşük düzeydedir. Ebeveynlerin bazıları, çocuklarının daha az aktif olmaların isteyebilir. Ebeveynlerin yanı sıra öğretmenler de, kronik hastalı̆̆ olan çocukların fiziksel aktivite ve oyuna katılımını teşvik etmede isteksiz olabilir (27). Çocuğun oyun oynama ve sportif faaliyetlere katılmasının fiziksel gereksinimleri arasında olduğu unutulmamalıdır. Ayrıca kronik hastalık nedeniyle hareket edebilmede sorunu olan birçok çocuğun tuvalete gidebilme, giyinip soyunma gibi faaliyetleri gerçekleştirebilmelerinde yardıma ve bağımsız gerçekleştirebilmelerinde çevre düzenlemelerine gereksinimleri vardır (21). Bazı kronik hastalıklarda uygun çevre düzenlemesi gerekmektedir. Örneğin, astım yönetiminde ortamın sıcaklığı, odanın/sınıfın havalandırılması, deodorant, oda parfümü gibi ürünlerin kullanımı gibi durumsal faktörlerin kontrolünü sağlamak önemlidir (27).

\section{Psikososyal Gereksinimler}

Kronik hastalığın çocukların yaşamında oluşturduğu değişiklikler, ailenin tutumu ve hastalığın merkezi sinir sistemini etkilemesi gibi nedenlerle duygusal, psikososyal ya da davranışsal gereksinimleri artmış ve bazı özel gereksinimleri ortaya çıkmış olabilir (28). Kronik hastalığı olan çocuklarda öfke nöbetleri, özgüven kaybı, sürekli dışlanma düşüncesi ve olumsuz benlik kavramı gibi sorunlar görülebilmektedir. Kronik hastalığı olan çocuklar okulda akran zorbalığına ve damgalanmaya maruz kalabilmektedir (20). Çocuğun okulda bu tür sorunlarla başetmek zorunda olması nedeniyle içe kapanma, sosyal izolasyon ve akran ilişkilerinden kaçınma görülebilmektedir. Çocukların psikososyal olarak desteklenmesi duygusal ve sosyal gelişimlerine katkı sağlayacaktır (29). Bakare ve arkadaşlarının (2008) çalışmasında, kronik hastalığı olan çocukların sağlıklı akranlarına göre duygularını kontrol etmede güçlük yaşadıkları belirtilmiştir. Kronik hastalığı olan çocukların duygusal değiş̧iklikleri ya da davranış bozukluklarının fark edilmesi ve liyezon hizmetinin geliştirilmesi önemli bir gereksinimdir (30).

\section{Akademik Gereksinimler}

Kronik hastalıklarla ilişkili olarak çocuklar fiziksel kısıtllılık, kontroller, psikososyal etkilenme ya da ebeveynlerin hastalığa yönelik algısı nedeniyle devamsızlık yapabilmektedir (31). Kronik hastalığı olan çocukların okul devamsızlı̆ğını sağlıklı akranlarına göre daha fazla olduğu belirtilmektedir $(29,32)$. Devamsızlık süresi hastalığın şiddetine göre farklılık göstermektedir (32). Eloi ve arkadaşlarının (2019) yaptığı çalışmada, inflamatuar bağırsak hastalığı olan çocuklar arasında okul devamsızlı̆̆ oratalama 5 gündür (33). Richardson ve arkadaşlarının (2018) çalışmasında, kronik böbrek yetmezliği olan çocukların \%17.3'ünün kronik okul devamsızlığının olduğu ifade edilmiştir (31). Yılmaz ve arkadaşlarının (2014) çalışmasında, kanser tedavisi gören çocukların sağlıklı akranlarına göre daha fazla okul devamsızlı̆̆ yaptığı belirtilmiştir (34). Tsimicalis ve arkadaşlarının (2018) çalışmasında, yeni kanser tanısı almış çocukların ebeveynleri en yaygın yaşanan kaybın okul devam durumunda olduğunu söylemişlerdir (35). Everhart ve arkadaşlarının (2018) çalışmasında, okul devamsızlığında astımın bir risk faktörü olduğu ifade edilmiştir (27).

Çocukların akademik başarıları ile okula devam durumları arasında bir iliş̧ki olduğu bilinmektedir (31). Okul devamsızlığı nedeniyle çocuklar derslerinde eleştirel bakış açısını geliştiremeyebilirler. Okula geri döndüklerinde uyum süreci ve katılamadı̆̆ı derslerin/konuların tekrarının olmaması nedeniyle akademik performansında azalma görülebilmektedir (34). Layte ve arkadaşlarının (2013) çalışmasında, okul devamsızlığı ve akran zorbalığına maruziyet sonucunda çocuklarda duygusal ve davranışsal sorunlar meydana geldiği ve bu durumun okul başarısını düşürdüğü ifade edilmiştir. Çalışma kronik hastalık ve okul başarısızlığı arasında anlamlı bir ilişki olduğunu göstermektedir. Çocukların akademik performansındaki azalmanın nedenlerinden birisi de bazı kronik hastalıkların nörobilişsel etkileridir (36). Lande ve arkadaşlarının (2011) çalışmasında, kronik böbrek yetmezliği olan çocukların akranlarına göre nörobilişsel fonksiyonlarının daha düşük olduğu görülmektedir (37). Crump ve arkadaşlarının (2013) çalışmasında, otizm, DEHB, epilepsi hastalıkları ve akademik performansın düşük olması arasında önemli bir ilişki saptanmıştır (38). Beyin tümörü olan, kraniyel radyoterapi ve/veya intratekal metotreksat tedavisi alan çocuklarda okuma, anlama, analiz etme gibi eğitim-öğretim faaliyetlerinde yetersizlik ve özel eğitime gereksinimin arttı̆̆ 1 belirtilmektedir (39). Çocukların okul motivasyonları ve okul başarısı için desteklenmeye gereksinimleri bulunmaktadır ( 3,31 , $32)$. 


\section{Kronik Hastalığı Olan Çocukların Okuldaki Bakımında Okul Hemşiresinin Görev ve Sorumlulukları}

Okul hemşireliği uygulamaları bireyselleştirilmiş profesyonel hemşirelik uygulamalarıdır. Bunlar çocuğun fiziksel, psikososyal ve akademik gereksinimlerini karşılamak, akademik başarısını ve yaşam süresini arttırmak, aktif ve potansiyel sağlık sorunlarını saptayıp tedavisi için girişimlerde bulunmak ve güvenli çevrenin oluşturulmasını sağlamak için yapılan uygulamalardır (5). Kronik hastalık yönetiminde okul hemşiresinin görevleri "çocuğun bakımı ve izlemi" (tablo 1), "eğitim ve danışmanlık hizmetleri" ve "sağlık politikaları, yönetsel durum" başlıkları altında aşağıda belirtilmiştir.

Tablo 1: Çocuğun Bakımı ve İzlemi

\begin{tabular}{|c|c|}
\hline Çocuğun bakımı ve izlemi & Okul hemşiresinin görev ve sorumlulukları \\
\hline Fiziksel değerlendirme & $\begin{array}{l}\text { Yaşamsal bulguların takibi } \\
\text { Boy-kilo takibi } \\
\text { Ağız ve diş sağlığı değerlendirmesi } \\
\text { Görme, işitme ve skolyoz taramaları }\end{array}$ \\
\hline Tedavi & $\begin{array}{l}\text { Sağlık bakım gereksinimlerinin değerlendirilmesi } \\
\text { Bireyselleştirilmiş bakım planının geliştirilmesi } \\
\text { İlaç kullanımının takibi } \\
\text { İlaçların yan etkilerin değerlendirilmesi } \\
\text { Kan glikoz ölçümlerinin ve sonuçlarının takibi } \\
\text { Aldığı-çıkardığı sıvı izlemi }\end{array}$ \\
\hline Acil durum müdahaleleri & $\begin{array}{l}\text { Acil eylem planının gelisstirilmesi } \\
\text { Acil durumlarda gerekli ilaçların hazır bulundurulması } \\
\text { Komplikasyon gelişme riski ve sıklığının değerlendirilmesi }\end{array}$ \\
\hline Beslenme & $\begin{array}{l}\text { Diyeti olan çocuklara beslenme takibi } \\
\text { Gerekli durumlarda diyetin düzenlenmesi } \\
\text { Diyabeti olan çocuklara karbonhidrat sayımının öğretilmesi } \\
\text { Ara ve ana öğünlerin takibi } \\
\text { Öğretmenlerin ara öğün konusunda bilgilendirilmesi } \\
\text { Okul kantininin denetlenmesi }\end{array}$ \\
\hline Fiziksel egzersiz-aktivite planlaması & $\begin{array}{l}\text { Çocukların fiziksel aktivitelere katılımının sağlanması } \\
\text { Gerekiyorsa bireysellesstirilmiş fiziksel aktivite planlaması } \\
\text { Egzersiz zamanının belirlenmesi }\end{array}$ \\
\hline Çevrenin düzenlenmesi & $\begin{array}{l}\text { Sinıf ve okulun hijyen koşullarının iyileştirilmesi } \\
\text { Alerjenlerin uzaklaştırılması } \\
\text { Hareketi kısıtlayan durumların giderilmesi } \\
\text { Revirin oluşturulması }\end{array}$ \\
\hline
\end{tabular}

\section{Çocuğun Bakımı ve İzlemi}

Fiziksel Değerlendirme: Okul hemşiresi, çocuğun boy, kilo ve beden kitle indeksini değerlendirir (40). Ağız ve diş muayenesini, görme, işitme ve skolyoz taramalarını yapar (41). Hastalık nedeniyle yaşamsal bulgularında meydana gelebilecek değişiklikleri izler ve değerlendirir (40). Çocuklarda düzenli büyüme ve gelişmeyi takip eder. Büyüme ve gelişmenin takibi çocuğun yaşına uygun gelişim özelliklerinde meydana gelen değişiklik ya da gerilemenin erken dönemde fark edilmesini sağlar. Hemşire gerekli gördüğünde ileri inceleme ve değerlendirme için yönlendirir (41).

Tedavi ve Acil Durum Müdahalesi: Çocukların okulda alması gereken ilaçları (insülin, bronkodilatör, antihipertansif vb.) kontrol eder. Okul hemşiresi, kullanılan gerekli ilaçların (insülin, glukagon, bronkodilatör, diazepam, midazolan, epinefrin, antibakteriyel pomad, antihistaminik pomad, alerjik göz damlası, ibubrofen) ve zirve akım ölçer (peak flow metre), nebulizatör, oksijen, oksijen maskesi, enjektörler, antiseptik, el dezenfektanı, alkol/povidon iyot, ilaç rehberi gibi malzemelerini revirde bulundurur (41). Kullanılan ilaçların halsizlik, konvülsiyon, baş ağrısı gibi olası yan etkilerini izler. Çocukların okulda kan glikoz düzeylerini ölçmesine yardım eder ve değerlendirir (42). Çocukların aldığı çıkardığı sıvı izlemini yapar (41).

Okul hemşiresi, çocuğun hastalığına ilişkin gelişebilecek komplikasyonları bilir. Çocukların muayene ve değerlendirme sıklığını belirler ve risk analizlerini yapar (43). Çocuklarda görülen komplikasyonların nedenlerini araştırır. Gerekli önlemlerin alınması konusunda ebeveynlere eğitim verir. Çocukların travma riskine yönelik önlemler alır (40). Acil durumlarda gerekli müdahale ve uygulamaları yapar (42). Okulda acil durumlarda kronik hastalık yönetiminin sağlanabilmesi için çocuk ve ebeveynlerle birlikte acil eylem planını geliştirir. Acil eylem planında çocukların rutin tedavisinde kullandığı ilaçlara, acil durum müdahalelerinde hangi ilaçların verileceğine, hastaneye transportunun nasıl yapılacağına ve ebeveynin onamına yer verir (44, 45). Hemşire kronik hastalığı olan çocukların sağlık bakım gereksinimlerini belirler ve vaka yönetimini yapar. Çocukların sağlık durumlarını değerlendirir ve ebeveynleri bilgilendirir. Çocuklara bireyselleştirilmiş bakım planı geliştirir (42). Çocukların sağlıkhastalık yönetiminde okul personeli ve doktoruyla iletişim halinde olur (41). 
Derleme

Beslenmenin Düzenlenmesi ve İzlemi: Hemşire, kronik hastalığına ilişkin özel diyeti olan ya da diyetinin düzenlenmesi gereken çocukların beslenme takibini yapar. Gerekli durumlarda diyetinin yeniden oluşturulmasını sağlar (46). Çocuğun ebeveynleri ve öğretmenlerini bilgilendirir. Bu sayede evde ve okulda diyetine uyumu sağlar (44). Örneğin; diyabeti olan çocuğa beslenmesinde karbonhidrat sayımını öğretir. Çocuğun kan glikoz düzeyini takip eder. Ara öğünlerini almasını sağlar ve ebeveynleri bilgilendirir (42). Sodyum kısıtlaması olan, yüksek kalorili ya da yüksek proteinli besin alması gereken çocukların diyetini düzenler (44). Okul yemekhanesindeki yemeklerin besin değerini denetler ve düzenler. Okulda öğün atlanmasını önler. Besin alerjisi olan çocuğun okulda tanınması hayati önem taşır. Okul yemekhanesinde ve kantinde çalışanlara yönelik eğitimler verir. Besin alerjisi olan çocuğun yiyeceklerini özel olarak hazırlatır (46).

Bireysel Fiziksel Egzersiz-Aktivite Planlaması: Okul hemşiresi kronik hastalığı olan çocukların ders dışı etkinliklere katılması için ebeveyn, öğretmen ve çocuğu teşvik eder. Kronik hastalığı olan çocukların öğretmenleri ya da ebeveynleri tarafından sıklıkla yapılan fiziksel egzersiz ve aktivitelerin gereksiz kısıtlanmasını önler. Çocuğun kronik hastalığı doğrultusunda fiziksel egzersiz planlamasını yapar. Örneğin; astımı olan çocuk için ısınma süresi uzun tutulmalıdır. Egzersiz sırasında dinlenme periyotları olmalıdır. Serebral palside ritmik hareketler ve eklemlere açısal egzersizler yaptırılmalıdır. Romatoid artritte yüzme ve bisiklet etkili ve yapılabilir egzersizlerdendir $(47,48)$. Okul hemşireleri, çocuklar, ebeveynler ve öğretmenlerin fiziksel aktiviteyle ilgili algıladıkları yanlışları önlemek/düzeltmek ve çocuk temelli egzersizin güvenli ve uygun olduğunu açıklamak için yönetim planı hazırlamalıdır. Ayrıca ebeveyn ve öğretmenlerle birlikte fiziksel egzersiz sırasında gelişebilecek olağan dışı durumlarla ilgili acil eylem planı hazırlamalıdır (44).

Çevrenin Düzenlenmesi: Okul hemşiresi, okulun çevresel düzenlenmesinde okul, sınıf ve tuvaletlerin fiziksel yapısı, havalandırma ve hijyenik koşullarını değerlendirir ve gereken önlemleri alır. Ortamda sıvı sızıntısı, küflenme gibi sorunların tespiti ve onarımı, yoğun kokuların (boya, vernik, duman gibi) ve alerjenlerin (ev tozu akarı, küf mantarı, hamamböceği, hayvan) giderilmesini sağlar (41). Okulda bakım, onarım ve temizlik gibi durumlarda kullanılan kimyasallardan çocukların uzak tutulmasını ve uygun havalandırmayı organize eder $(42,45)$. Fiziksel yetersizliği olan çocukların hareketini engelleyen çevre koşullarının (giriş-çıkışlarda tekerlekli sandalyeye uygun rampa, tuvaletlerin fiziksel olarak uygunluğu, sınıfta sırasına rahat bir şekilde yerleşebilmesi için uygun yere oturtulması, sıranın yüksekliği, sıraların arasında uygun mesafelerin olması gibi) düzenlenmesini sağlar (49). Astımı olan çocukların fiziksel aktivite yapacağı ortamın koşullarına (nemli, soğuk olmayan vb.) uygun ortam düzenlemesini yapar (47). Çocukların sağlı//hastalık gereksinimlerinin güvenli bir şekilde karşılanabilmesi için uygun bir ortam hazırlar (1).

\section{Ĕ̆itim ve Danışmanlık Hizmetleri}

Okul hemşiresi, öğrencilerin, ebeveynlerin, öğretmenlerin ve okul personelinin eğitim gereksinimlerini belirler. Eğitim vereceği birey ya da grubun gereksinimine yönelik eğitimleri düzenler. Eğitim konuları gereksinimlere göre çeşitlendirilebilir (44, 50). Okul hemşiresinin eğitim ve danışmanlık hizmetleri fiziksel bakımda eğitim ve danışmanlık, psikososyal bakımda eğitim ve danışmanlık, akademik konularda eğitim ve danışmanlık olarak üç bölümde ele alınmıştır.

Fiziksel Bakımda Ĕğitim ve Danışmanlık: Ebeveynlere ve çocuklara yeterli ve dengeli beslenme, diyete uyum, yiyecek alerjisi, kalori miktarı, besin türü vb. (48), fiziksel egzersiz, tedaviye uyum, hastalık semptomlarını yönetme (51), kronik hastalıkla yaşam eğitimleri verilebilmektedir (50). Öğretmenlere verilebilecek eğitimler arasında beslenme, diyete uyum ve yiyecek alerjisi (48), fiziksel güç gerektiren derslere ya da aktivitelere katılma, dinlenme gereksinimi, bulaşıcı hastalıklara karşı önlemleri bilme, semptomları tanıma ve acil durumlara karar verebilme yer alabilmektedir (50). Diğer çocuk ve ebeveynlere acil durumda yapılması gerekenler konusunda eğitim verilebilmektedir (52).

Psikososyal Bakımda Ĕgitim ve Danışmanlık: Kronik hastalık, çocuğun ve ebeveynin psikolojik ve sosyal uyum sorunları yaşamasına neden olabilir. Çocuğun ve ailesinin uyumunu arttırmada en etkili yöntem baş etme becerilerinin geliştirilmesidir (53). Ebeveynlere ve çocuklara psikososyal destek (4) ve başa çıkma eğitimleri verilebilmektedir (40). Ayrıca sağlıklı çocuklara ve ebeveynlerine akran ilişkileri ve akran zorbalığı konularında eğitimler düzenlenebilmektedir (52). Kronik hastalığ1 olan çocukların zaman zaman motivasyonları düşebilir, benlik saygısı azalabilir ve bu durum akademik performansında azalma ve okul devamsızlığında artış ile sonuçlanabilmektedir. Çocuklarla motivasyon artırıcı çalışmalar yapmak ve öğretmenleri bu yönde desteklemek etkili olabilmektedir (54). Yapılan çalışmalarda benzer hastalığı olan kişilerle birlikte olmanın çocuk ve ebeveynde görülen psikososyal sorunları azalttığı ifade edilmektedir (55). Okul hemşiresi, çocuklara ve ebeveynlere, benzer hastalığı olan çocukların yer aldığı sosyal gruplar, dernekler ve sivil toplum kuruluşları konusunda danışmanlık verebilir.

Akademik Konularda Ĕ̆itim ve Danışmanlık: Komplikasyonlar, kontroller ya da hastaneye yatma nedeniyle yapılan okul devamsızlığının azaltılması okul hemşireliği uygulamaları ile mümkündür. Okul hemşiresi, çocuğun düzenli takibini ve risk değerlendirmelerini yapmalı ve ebeveyn ile iş birliği içerisinde olmalıdır. Ayrıca bireysel başetme becerisinin geliştirilmesi, motivasyonu arttırma çalışmaları ile kronik hastalık yönetimi kontrol altında olabilmektedir. Bu sayede çocuğun acil durum yaşama sıklığında azalma sağlanırken hastalığın prognozundaki kötüleşmeler önlenebilecektir (56). Çocukların okul devamsızlığ 1 nedeniyle olumsuz etkilenen akademik performansını iyileştirmek için öğretmenlere çocukların akademik performansı ile kronik hastalık arasındaki ilişki ve çocuğun okula uyum süreci konularında eğitim verilebilmektedir. Okul hemşiresi, devamsızlığın ardından okula dönen çocuğa uyum ve başarısını arttıracak yöntemleri çocuğa özel olarak öğretmen ve ebeveynlerle birlikte planlanmalıdır. Bu süreçte hemşire, değerlendirmeleri ve yöntemlerin etkinliğini objektif olarak yapabilmelidir (52). Okul hemşireliği sadece hemşirelik uygulamalarından değil aynı zamanda çocuk, aile ve okul personelinin eğitiminden ve sağlı/hastalık ile ilgili müfredattan sorumludur. Okul hemşiresi, çocukların öğrenmeye hazır oluşunu sağlamaktadır (56). 


\section{Sağlık Politikaları ve Yönetsel Durum}

Amerikan Ulusal Okul Hemşireleri Birliğgi’nin tanımına göre okul hemşiresi; çocukların iyi oluşları, akademik başarısı ve yaşam boyu gelişimi için çocukların var olan ve potansiyel sağlık sorunlarına müdahale eden, vaka yönetimini yapan, sağlık ve güvenliklerini korunmak için teşvik eden, özdenetim, uyum, özveri ve öğrenme, çocuk ve ailenin kapasitesini geliştirmek için diğerleriyle iş birliği yapan sağlık profesyonelidir (57). Okul hemşiresinin kronik hastalığı olan çocuk ve adölesanların sağlığını geliştirmek ve eğitimdeki başarısını güçlendirmek için gerçekleştirdiği rolleri bulunmaktadır. Bu roller:

- Kronik sağlık sorunlarının yönetimini kapsayan bakım hizmeti verir.

- Çocukların sağlık bakım gereksinimlerinin tespit edilmesi ve karşılanmasında planlamayı gerçekleştirir.

- Çocukların sağlık durum tespiti için tarama programlarını geliştirerek çocukların olası sağlık sorunlarını erken dönemde tespit eder.

- Çocukların ihtiyaçları doğrultusunda çocuklara bireysel ya da grup eğitimleri organize eder. Ayrıca sağlık eğitimi müfredatını geliştirme takımında görev alır.

- Okul hemşiresi, sağlık bakım uzmanı olarak okul sağlığı politikalarının geliştirilmesine liderlik eder $(42,50,57)$.

Okul hemşiresi, sağlığın geliştirilmesi ve korunması, kronik hastalıkların yönetimi, okul sağlığı programların koordinasyonu, kriz yönetimi, acil tıbbi durum yönetimi, ruh sağlığı koruma ve müdahale, akut hastalık yönetimi ve bulaşıc1 hastalıklardan koruma ve yönetiminde okul sağlığı politikalarının düzenlenmesi ve geliştirilmesinde danışman, organizatör ve sağlayıcı olarak görev almaktadır (42). Ülkemizde Hemşirelik Yönetmeliği’nde okul hemşirelerinin görev, yetki ve sorumlulukları tanımlanmıştır (58). Ancak çok az okul hemşiresi istihdam edilmektedir. Okul hemşiresi, sağlık sistemi ile eğitim arasında önemli bir köprüdür. Ülkemizde okul hemşiresinin popülasyonuna ilişkin yeterli bilgi bulunmamaktadır. Amerika'da devlet okullarının \%18.1'i okul hemşiresi desteği almamaktadır. Kamu ve özel okullarda tam ya da yarı zamanlı 132300 okul hemşiresi istihdam etmektedir. Okul hemşireliği, çocuk ve adölesanlara sağlık bakım hizmetini evrensel olarak erişilebilir kılan bir meslektir. Bu nedenle okullarda hemşire istihdamının gerekliliği kaçınılmaz bir gerçektir (59).

\section{Sonuç}

Çalışmamızda kronik hastalığı olan çocukların okuldaki fiziksel, psikososyal ve akademik gereksinimleri ile okul hemşiresinin görev sorumlulukları incelenmiştir. Çocukların okuldaki gereksinimlerinin karşılanmaması, onları pek çok yönden olumsuz bir şekilde etkileyebilmektedir. Bu nedenle çocukların iyi oluşları için okuldaki gereksinimleri sağlık profesyoneli tarafından karşılanmalıdır. Okul sağlığı hemşiresi, çocukların sağlığının geliştirilmesi ve hastalıkların yönetiminde etkili bir uzman olarak ülke ekonomisine sağladığı katkı ile toplum refahını arttıracaktır. Dünya örneklerinde olduğu gibi ülkemizde de okul sağlığı hemşirelerinin istihdamının gerekli olduğu düşünülmektedir.

\section{Bilgilendirme}

Bu derlemeye yazarların katkı oranı beyanı şu şekildedir: Fikir/kavram NA, GÇ; tasarım GÇ, NA; denetleme/danışmanlık NA; literatür tarama GÇ; analiz/yorumlama NA, GÇ; makalenin yazımı GÇ, NA; eleştirel düşünme GÇ, NA; son kontrollerin yapılması NA, GÇ. Derleme yazımı ile ilgili herhangi bir kurum ya da kuruluştan destek alınmamıştır. Bu derleme araştırma ve bilimsel yayın etiğine uyularak yazılmıştır. Araştırmacılar arasında herhangi bir çıkar çatışması bulunmamaktadır.

\section{Kaynaklar}

1. O’Connor M, Rosema S, Quach J, Kvalsvig A, Goldfeld, S. Parent and teacher perceptions of emerging special health care needs. Journal of Paediatrics and Child Health 2016;52(10):950-956.

2. Perrin JM, Gnanasekaan S, Delahaye J. Psychological aspects of chronic health conditions. Pediatrics in Review 2012;33(3):1-8.

3. Pansier B, Schulz PJ. School-based diabetes interventions and their outcomes: A systematic literature review. Journal of Public Health Research 2015;4(467):65-71.

4. American Academy of Pediatrics Council on School Health. Role of the school nurse in providing school health services. Pediatrics 2016;137(6):1-8.

5. National Association of School Nursing. Definiton of scool nursing. 2017;URL:http://www.websitation.org/query?url=http\%3A\%2F\%2Fwww.nasn.org\%2Fabout-nasn\%2Fabout\&date=2018$10-04$.

6. Morse BL, Anderson L, Combe LG, Delack S, Ondeck L. U.S. school nursing job analysis. The Journal of School Nursing 2020:1-12.

7. Rodríguez-Almagro J, Hernández-Martínez A, Alarcón-Alarcón G, , Infante-Torres N, Donate-Manzanares M, GomezSalgado J. The need for school nursing in Spain: A mixed methods study. International Journal of Environmental and Public Health 2018;15(11):2367.

8. Wang, LY, Vernon-Smiley, M, Gapinski, MA, Desisto M. Cost-benefit study of school nursing services. The Journal of the American Medical Association Pediatrics 2014;168(7):642-648. doi:10.1001/jamapediatrics.2013.5441.

9. Word Health Organization. Noncommunicable diseases. 2018; URL:http://www.who.int/news-room/factsheets/detail/noncommunicable-diseases.

10. Centers for Disease Control and Prevention. About chronic disease. 2019; URL: https://www.cdc.gov/chronicdisease/about/index.htm.

11. Rolland JS. Chronic illness and life cycle: A conceptual framework. Family Process 1987;26:203-221

12. Copley MF, Bodensteiner JB. Chronic sorrow in families of disabled children. Journal of Child Neurology 1987;2(1):67-70 
Derleme

13. Olshansky S. Chronic sorrow a response to having a mentelly defective child. Families in Society: The Journal of Contemporary Social Services 1962;43(4):190-193.

14. Centers for Disease Control and Prevention. Most recent national asthma data. 2019; URL: https://www.cdc.gov/asthma/most_recent_national_asthma_data.htm.

15. Centers for Diseases Control and Prevention National Center for Health Statistics. Health, United States, 2016: With chartbook on long-term trends in health. Hyattsville, MD. 2017.

16. Centers for Disease Control and Prevention. New data on autism spectrum disorder in 4-year-old children. 2019; URL: https://www.cdc.gov/ncbddd/autism/features/asd-data-four-year-old-children.html.

17. Devlet İstatistik Enstitüsü. Türkiye özürlüler araştırması-2002 (2. Bask1), Ankara: Devlet İstatistik Enstitüsü Matbaası.2009.

18. Compas BE, Jaser S, Dunn MJ, Rodriguez EM. Coping with chronic illness in childhood and adolescence. Clinical Psychology Reiew 2012;27(8):455-480.

19. Bell MF, Bayliss DM, Glauert R, Harrison A, Ohan JL. Chronic illness and developmental vulnerability at school entry. Pediatrics 2016;137(5):1-9.

20. Quach LL, John RM. Psychosocial of impact growing up with food allergies. The Journal of Nurse Practitoners 2018;14(6):477-483.

21. Compas BE, Jaser S, Dunn MJ, Rodriguez EM. Coping with chronic illness in childhood and adolescence. Clinical Psychology Reiew 2012;27(8):455-480.

22. Sevilla MA. Nutritional considerations in pediatric chronic disease. Pediatrics in Review 2017;38(8):343-352.

23. Trivic I, Hojsak I. Evaluation and treatment of malnutrition and associated gastrointestinal complications in children with cerebral palsy. Pediatric Gastroenterology, Hepatology \&Nutrition 2019;22(2):122-131.

24. Richardson KL, Weiss NS, Halbach S. Chronic school absenteeism of children with chronic kidney disease. The Journal of Pediatrics 2018;199:267-271.

25. Constance AC. Nutrition issues for youth with diabetes. National Association of School Nurses 2014;29(5):230-231.

26. Bioletti L, Capuano MT, Vietti F, Cesari L, Emma L, Leggio K, et al. Celiac disease and school food service in Piedmont Region: Evaluation of gluten-free meal. Annali di Igiene, Medicina Preventiva e di Comunità 2016;28(2):145-157.

27. Everhart RS, Miller S, Leibach GG, Dahl AL, Oinis-Mitchell D. Caregiver asthma in urban families: Implications for school absenteeism. The Journal of School Nursing 2018;34(2):108-113.

28. Balkan S, Yılmaz S, Özbaran B, Erermiş S, Gökben S, Tekgül H. ve ark. Çocukluk çağı epilepsilerinde çocuk yaşam kalitesi: Hastalık eğitiminin rolü. The Journal of Pediatric Research 2015;2(3):144-151.

29. Jansen PW, Verlinden M, Dommisse-van Berkel A, Mieloo CL, Raat H, Hofman A, et al. Teacher and peer reports of overweight and bullying among young primary school children. Pediatrics 2014;134(3):473-480.

30. Bakare MO, Omigbodun OO, Kuteyi OB, Meremikwu MM, Agomoh AO. Psychological complications of childhood chronic physical illness in Nigerian children and their mothers: The implication for developing pediatric liaison services. Child and Adolescent Psychiatry and Mental Health 2008;2(34):1-9.

31. Richardson KL, Weiss NS, Halbach S. Chronic school absenteeism of children with chronic kidney disease. The Journal of Pediatrics 2018;199:267-271.

32. Hoffmann I, Diefenbach C, Graf C, Konig J, Schmidt MF, Schnick-Vollmer K et al. Chronic health conditions and school performance in first graders: A prospective cohort study. PLOS ONE 2018;13(3): 1-15.

33. Eloi C, Foulon G, Bridoux-Henno L, Breton E, Pelatan C, Chaillou E et al. Inflammatory bowel diseases and school absenteeism. Journal of Pediatric Gastroenterology and Nutrition 2019;68(4):541-546.

34. Yılmaz MC, Yıldırım-Sarı H, Cetingul N, Kantar M, Erermis S, Aksoylar S. Determination of school-related problems in children treated for cancer. The Journal of School Nursing 2014;30(5):376-384.

35. Tsimicalis A, Genest L, Stevens B, Ungar WJ, Barr R. The impact of a childhood cancer diagnosis on the children and siblings' school attendance, performance, and activities: A qualitative descriptive study. The Journal of Pediatric Oncology Nursing 2018;35(2):118-131.

36. Layte R, McCrory C. Paediatric chronic illness and educational failure: The role of emotional and behavioural problems. Social Psychiatry \& Psychiatric Epidemiology 2013;48(8):1307-1316.

37. Lande MB, Gerson AC, Hooper SR, Cox C, Matheson M, Mendley RS, et al. Casual blood pressure and neurocognitive function in children with chronic kidney disease: A report of the children with chronic kidney disease cohort study. Clinical Journal of the American Society Nephrology 2011;6(8):1831-1837.

38. Crump C, Rivera D, London R, Landau M, Erlendson B, Rodriguez E. Chronic health conditions and school performance among children and youth. Annals of Epidemiology 2013;23(4):179-184.

39. Gurney JG, Krull KR, Kadan-Lottick N, Nicholson HS, Nathan PC, Zebrack B, et al. Social outcomes in the childhood cancer survivor cohort. Journal of Clinical Oncology 2009;27(14):2390-2395.

40. Törüner EK, Büyükgönenç L. Çocuk sağlığı: Temel hemşirelik yaklaşımları. 1. Basım. Ankara: Nobel Tıp; $2017: 122,732$.

41. Unikel LH, Evans D, Bornstein L, Surrence K, Mellins RB. Asthma knowledge and asthma management behavior in urban elementary school teachers. Journal of Asthma 2010;47(2):185-191.

42. Leroy ZC, Wallin R, Lee S. The role of school health services in addressing the needs of students with chronic health conditions: A systematic review. Journal of School Nursing 2017;33(1):64-72.

43. Centers for Disease Control and Prevention. Seizure first aid. 2019; URL: https://www.cdc.gov/epilepsy/about/first-aid.htm. Kasim 25, 2019.

44. Staudt, AM, Alamgir H, Long DL, Inscore SC, Wood PR. Developing and implementing a citywide asthma action plan: A community collaborative partnership. Southern Medical Journal 2015;108(12):710-714. 
Derleme

45. National Asthma Council Australia. Asthma action plans. 2017;URL:https://www.nationalasthma.org.au/healthprofessionals/asthma-action-plans/. Eylül 22,2018.

46. Yabancı N. Okul sağlığı ve beslenme programları. Türk Silahli Kuvvetler Koruyucu Hekimlik Bülteni 2011;10(3):361-368.

47. Sağlık Bakanlığı. Halk Sağlığı Genel Müdürlüğü, Çocuk ve ergen için kronik hastalıklarda fiziksel aktivite rehberi. Yayın No: 1089. 1. Bask1. Ankara; 2018.

48. Yüzer S, Polat, S. Çocuklar ve spor. Türk Silahli Kuvvetler Koruyucu Hekimlik Bülteni 2014;3(3):241-244.

49. Mülayim A. İç mekân düzenlemesinde engellilere yönelik çözüm önerileri. Kirklareli University Journal of Engineering and Science 2017;3:68-94.

50. Bektaş M, Aydın B. Okul hemşiresinin rol ve işlevleri. Turkiye Klinikleri Pediatric Nursing-Special Topics 2018;4(1):5264.

51. Toyran M, Kocabaş C. Okul ve allerjik hastalığı olan çocuk. Türkiye Çocuk Hastalıkları Dergisi 2014;8(4):223-228.

52. McClanahan R, Weismuller PC. School nurses and care coordination for children with complex needs: An integrative review. Journal of School Nursing 2015;31(1):34-43.

53. Özdemir Ü, Taşçı S. Kronik hastalıklarda psikososyal sorunlar ve bakım. Erciyes Üniversitesi Sağlık Bilimleri Fakültesi Dergisi 2013;1(1):57-72.

54. Mattson G, Kuo DZ, Committee on psychosocial aspects of child and family health, council on children with disabilities. Psychosocial factors in children and youth with special health care needs and their families. Pediatrics 2010;143(1):1-16.

55. Altundağ S. Tip 1 diyabetli çocukların hastalığa uyumunda eğitimin ve sosyal desteğin etkisi. Pamukkale Tıp Dergisi 2018;11(2):137-144.

56. Best NC, Oppewal S, Travers D. Exploring school nurse interventions and health and education outcomes: An integrative review. Journal of School Nursing 2018;34(1):14-27.

57. American Academy of Pediatrics, Council on School Health. Role of the school nurse in providing school health services. Pediatrics 2008;121(5):1052-1056.

58. Sağlık Bakanlığı. Hemşirelik yönetmeliğinde değişiklik yapılmasına dair yönetmelik. Okul sağlı̆̆ı hemşiresi: Görev, yetki ve sorumlulukları, Hemşirelik yönetmeliği (19 Nisan 2011) T.C. Resmi Gazete, 27910; 2011.

59. Willgerodt MA, Brock DM, Maughan ED. Public school nursing practice in the United States. Journal of School Nursing 2018;34(3):232-244. 